\title{
STUDI KONSENTRASI GULA TERHADAP KARAKTERISTIK HARD CANDY SARI TERONG PIPIT
}

\author{
Syahrudin ${ }^{(1)}$ dan R. Marwita Sari Putri, S.Pi., M.Si ${ }^{(2)}$ \\ (1) Alumni Teknologi Pangan Faperta UNISI \\ (2) Dosen Universitas Maritim Raja Ali Haji Tanjung Pinang \\ 2012wita@gmail.com
}

\begin{abstract}
Abstrak
Tujuan penelitian ini adalah untuk mengetahui konsentrasi gula yang tepat dalam pembuatan permen keras (Hard Candy) berbahan dasar terong pipit sehingga menghasilkan karakteristik fisik, kimia dan sensori yang baik. Dari hasil penelitian bahwa permen terong pipit yang terbaik adalah pada perlakuan D (1000 gr gula pasir/bb) dengan kadar gula total $43.824 \%$ dan kadar air 5.5482\%. Dari hasil uji kadar gula sakarosa sudah memenuhi standar SNI yaitu kadar sakarosa min 40\%/bb, namun pada uji kadar air belum memenuhi standar SNI yaitu kadar air maksimal $3,5 \% / \mathrm{bb}$.
\end{abstract}

Kata Kunci : hardcandy, permen, terong pipit

\section{PENDAHULUAN}

Terong pipit memiliki ukuran yang sangat kecil dibandingkan dengan terong-terong lain. Terong pipit berwarna hijau dan bentuknya bulat. Terong pipit rasanya agak pahit kalau dimakan. Di Kabupaten Indragiri Hilir buah terong pipit pipit sangat mudah ditemui. Terong pipit terkadang ditanam dipekarangan rumah. Pada umumnya terong pipit hanya dibuat sayuran dan terkadang terong pipit dibiarkan membusuk dipohonnya. Di Inhil buah terong pipit belum dibudidayakan secara masal. Hal ini dikarenakan kurangnya pemanfaatan buah terong pipit. Sehingga belum ada petani yang membudidayakan terong pipit secara masal.

Terong pipit mengandung banyak khasiat bagi kesehatan dan termasuk salah satu tanaman obat. Adapun kandungan kimia pada terong antara lain; saponin, tanin, flavonid, alkaloid, protein, lemak, kalsium, fosfor, zat besi serta vitamin $\mathrm{A}, \mathrm{B}$ dan $\mathrm{C}$ yang dapat dimanfaatkan sebagai obat jantung berdebar (daun), kepala pusing, kurang nafsu makan serta tekanan darah tinggi (daun dan buahnya). Terong pipit juga berperan sebagai imunomodulator (menjaga kekebalan tubuh) (Wahyu, 2014). Terong pipit dapat menyehatkan mata, mengandung sedikit zat besi, vitamin A, C dan B1. Selain itu di dalam terong pipit juga terkandung $2 \%$ protein, $0.1 \%$ lemak, 7,9 karbohidrat dan banyak mengandung fosfor (Hidayat, 2014).

Pemanfaatan buah terong pipit oleh masyarakat Indragiri Hilir belum dimanfaatkan secara optimal padahal buah terong pipit banyak mengadung manfaat bagi kesehatan tubuh. Biasanya terong pipit hanya diolah sebagai sayuran yang di masak untuk lauk pauk kebutuhan dapur, padahal buah ini juga dapat di olah sebagai bahan olahan jadi yang bernilai tinggi untuk menciptakan penganekaragaman pangan salah satunya 
terong pipit dapat diolah menjadi permen.

Permen adalah sejenis gula yang dibuat dengan mencairkan gula di dalam air. Permen pada dasarnya adalah campuran dari gula, sirup glukosa atau gula invert, air, flavour dan pewarna. Selain berbahan dasar gula, komponen flavour juga sangat penting dalam pembuatan permen. Pada pra penelitian penulis telah melakukan pengolahan permen dari bahan dasar sari terong pipit. Permen terong pipit dibuat dengan perbandingan 1 (500 gr terong pipit + $500 \mathrm{ml}$ Air $=500 \mathrm{ml}$ sari terong pipit) $: 2$ (1 $\mathrm{kg}$ gula) menghasilkan permen dengan tekstur yang keras.

Pemanfaatan dan pengembangan terong pipit di Indonesia belum dilakukan secara optimal, sehingga menjadi nilai jual yang sangat rendah bahkan di Indragiri Hilir belum ada yang mengembangkan produk hasil dari terong pipit sehingga terong pipit kurang dimanfaatkan. Dengan demikian salah satu cara pengembangan terong pipit adalah dijadikan permen.

Masalah utama dalam pengolahan permen keras terong pipit adalah belum diketahuinya konsentrasi gula yang tepat untuk menghasilkan karakteristik yang baik, dengan demikian penulis melakukan penelitian dengan judul "Studi Konsentrasi Gula terhadap Karaktersitik Hard Candy Sari Terong Pipit (Solanum Torvum)".

\section{Tujuan Penelitian}

Tujuan penelitian ini adalah untuk mengetahui konsentrasi gula yang tepat dalam pembuatan permen keras (Hard Candy) berbahan dasar terong pipit sehingga menghasilkan karakteristik fisik, kimia dan sensori yang baik.

\section{Manfaat Penelitian}

Manfaat penelitian ini adalah :

1. Memberikan pengetahuan kepada masyarakat tentang kandungan gizi buah terong pipit serta manfaatnya bagi kesehatan.

2. Memberikan alternatif kepada masyarakat untuk mengolah buah terong pipit yang belum banyak dimanfaatkan menjadi suatu produk yang bermanfaat dan dapat menjadi nilai ekonomi tinggi.

\section{METODOLOGI PENELITIAN}

\section{Bahan}

Bahan yang digunakan di dalam penelitian ini adalah terung pipit yang masih muda (warna hijau), air, asam jawa, dan gula pasir putih bersih (sukrosa). Adapun bahan yang digunakan untuk analisis gula reduksi : Aquades, $\mathrm{Pb}$ asetat, Na-Oksalat, $\mathrm{Na}$ Hidrat, larutan luffschoorl (KI), $\mathrm{H}_{2} \mathrm{SO}_{4}$, dan Na-Thiosilfat.

\section{Alat}

Alat yang digunakan di dalam penelitian ini adalah timbangan analitik, oven, pisau, baskom, kompor, cetakan permen, panci, kain saring. Adapun alat yang digunakan untuk analisa kimia yaitu pengujian gula reduksi : timbangan, labu takar, erlenmeyer, dan incubator. Uji kadar air : cawan porselen, oven, dan desikator.

\section{Metode Penelitian}

Rancangan percobaan yang digunakan di dalam penelitian ini adalah Rancangan Acak Lengkap (RAL) terdiri dari empat perlakuan yaitu :

$\mathrm{A}=250 \mathrm{gr}$ gula $\mathrm{pasir} / \mathrm{bb}(500 \mathrm{gr})$

$\mathrm{B}=500 \mathrm{gr}$ gula pasir/bb (500 gr)

$\mathrm{C}=750$ gr gula pasir/bb (500 gr)

$\mathrm{D}=1000 \mathrm{gr}$ gula pasir/bb (500 gr) 
Perlakuan ini diulang sebanyak 3 kali sehingga diperoleh perlakuan 4 x 3 dengan jumlah 12 satuan unit percobaan. Model rancangan yang digunakan adalah sebagai berikut :

$\mathrm{Y}_{\mathrm{ij}}=\mu+\mathrm{P}_{\mathrm{i}}+\mathrm{E}_{\mathrm{ij}}$

Di mana :

$\mathrm{Y}_{\mathrm{ij}} \quad$ : Hasil pengamatan

$\mu \quad$ : Rata-rata

$\mathrm{P}_{\mathrm{i}} \quad$ : Pengaruh

E : Pengaruh sisa pada satuan percobaan yang mendapatkan perlakuan (1-4) pada ulangan (13)

i : Perlakuan

j : Ulangan (1-3)
Hasil data dianalisa secara statistik, jika $\mathrm{F}$ hitung > dari $\mathrm{F}$ tabel, maka dilakukan uji lanjut BNJ taraf nyata $5 \%$.

\section{HASIL DAN PEMBAHASAN}

\section{Kadar Gula (Sakarosa)}

Hasil statistik dari perlakuan penambahan gula pada pembuatan permen terong pipit berbeda nyata pada taraf $5 \%$ terhadap kadar gula $\mathrm{F}$ hitung (94.628) > F tabel (4.067). Kadar gula permen terong pipit yang dihasilkan setelah uji lanjut dilakukan dapat dilihat pada Tabel 1.

Tabel 1. Rata-rata Penilaian Kadar Gula terhadap Permen Terong Pipit.

\begin{tabular}{|l|l|}
\hline \multicolumn{1}{|c|}{ Perlakuan } & \multicolumn{2}{|c|}{ Rata-rata Kadar Gula (\%) } \\
\hline $\mathrm{D}=1000$ gr gula pasir/bb & 43.824 a \\
$\mathrm{C}=750$ gr gula pasir/bb & $39.109 \mathrm{~b}$ \\
$\mathrm{~B}=500$ gr gula pasir/bb & $37.695 \mathrm{~b}$ \\
$\mathrm{~A}=250$ gr gula pasir/bb & $37.692 \quad \mathrm{~b}$ \\
\hline
\end{tabular}

Keterangan : Angka-angka yang diikuti oleh huruf dan pada kolom yang sama berarti berbeda tidak nyata menurut uji duncan taraf $5 \%$.

Dari Tabel 1 dapat dilihat ratarata kadar gula dalam permen terong pipit berkisar antara $37.692 \%-43.824 \%$. Kandungan gula terbanyak terdapat pada perlakuan D (1000 gr gula pasir/bb) dengan nilai $43.824 \%$ dan terendah pada perlakuan A (250 gr gula pasir/bb) dengan nilai $37.692 \%$. Semakin tinggi konsentrasi gula yang ditambahkan pada pembuatan permen terong pipit maka kadar gula semakin tinggi. Hal ini sesuai dengan pendapat Nuzulqi (2015) peningkatan kadar gula disebabkan karena banyaknya sakarosa maupun glukosa yang ditambahkan kedalam bahan pangan.

Menurut Suhardi dan Tranggono, dkk (1999), bahwa banyaknya gula yang ditambahkan dalam bentuk monosakarida (glukosa, fruktosa) dan disakarida (sukrosa) akan menentukan kemanisan.

Penggunaan sukrosa sebagai pemanis bertujuan untuk meningkatkan cita rasa. Disamping itu juga digunakan sebagai pengawet karena tekanan osmosisnya yang tinggi menyebabkan terjadinya plasmolysis yang mengakibatkan kematian sel bagi mikroba (Buckle, 1987). Dalam uji kadar gula sakarosa telah memenuhi standar SNI yaitu kadar gula sakarosa min $40 \% / \mathrm{bb}$.

\section{Kadar Air}

Air merupakan komponen penting dalam bahan pangan yang dapat mempengaruhi penampakan, tekstur dan cita rasa makanan. Kadar air dalam bahan makanan ikut menentukan kesegaran dana daya awet bahan 
makanan tersebut (Winarno, 1991). Hasil statistik dari perlakuan penambahan gula pada pembuatan permen terong pipit berbeda nyata pada taraf 5\% F hit (31.460) > F (4.067).
Rata-rata pengaruh penambahan gula terhadap kadar air pada permen terong pipit yang dihasilkan setelah uji lanjut dilakukan dapat dilihat pada Tabel 2.

Tabel 2. Rata-rata Penilaian Kadar Air terhadap Permen Terong Pipit.

\begin{tabular}{|l|r|}
\hline \multicolumn{1}{|c|}{ Perlakuan } & \multicolumn{2}{|c|}{ Rata-rata Kadar Air (\%) } \\
\hline $\mathrm{A}=250$ gr gula pasir/bb & 10.075 a \\
$\mathrm{B}=500$ gr gula pasir/bb & $8.077 \quad \mathrm{~b}$ \\
$\mathrm{C}=750$ gr gula pasir/bb & $6.595 \quad \mathrm{c}$ \\
$\mathrm{D}=1000$ gr gula pasir/bb & $5.548 \quad \mathrm{~d}$ \\
\hline
\end{tabular}

Keterangan : Angka-angka yang diikuti oleh huruf dan pada kolom yang sama berarti berbeda tidak nyata menurut uji duncan taraf $5 \%$.

Dari Tabel 2 dapat dilihat ratarata kadar air dalam permen terong pipit berkisar antara $5.548 \%-10.075 \%$, dari hasil uji lanjut untuk semua perlakuan berbeda nyata. Kandungan air terbanyak terdapat pada perlakuan A (250 gr gula pasir/bb) dengan nilai $10.075 \%$ dan terendah pada perlakuan D (1000 gr gula pasir/bb) dengan nilai $5.548 \%$. Jadi semakin besar konsentrasi gula yang ditambahkan pada pembuatan permen terong pipit, maka kandungan air dalam permen akan semakin sedikit. Sebaliknya semakin kecil konsentrasi gula yang ditambahkan pada pembuatan permen terong pipit, maka kandungan air dalam permen akan semakin banyak. Hal ini sesuai dengan sifat gula sukrosa yang bersfiat higroskopis, yaitu kemampuan untuk menyerap dan menahan air (Wiloiams, 2001). Pada larutan gula yang memiliki konsentrasi tinggi akan menimbulkan tekanan osmotik tinggi, maka akan lebih tinggi pula kemampuan menarik cairan buah. Selain itu berat molekul gula yang relatif rendah dapat mempertahankan produk menjadi lebih stabil (Winarno, 1997).

Menurut Buckle (1987) bahwa apabila gula ditambahkan ke dalam bahan pangan dalam konsentrasi yang tinggi (paling sedikit $40 \%$ padatan terlarut) sebagian dari air yang ada tidak tersedia untuk pertumbuhan mikroorganisme dan aktivitas air dari bahan pangan berkurang. Menurut Athy (1979) bahwa diduga pada tekanan yang lebih besar atau konsentrasi gula yang lebih besar dapat menghambat aktivitas mikroba, dan penambahan gula juga berpengaruh pada kadar air dan berat.

Larutan sukrosa diuapkan maka konsentrasinya akan meningkat, demikian juga dengan titik didihnya. Keadaan ini terus berlangsung sehingga air menguap semua dan keseluruhan larutan merupakan cairan sukrosa yang lebur (Winarno, 2008).

Menurut Winarno (2002), semua bahan makanan mengandung air dalam jumlah yang berbeda beda, baik itu bahan makanan hewani maupun nabati dan kadar air bahan baku akan mempengaruhi kadar air dari produk hasil olahan. Pada uji kadar air pada permen terong pipit belum memenuhi standar SNI yaitu kadar air maksimal $3,5 \% / b b$.

\section{KESIMPULAN DAN SARAN}

\section{Kesimpulan}

Dari hasil penelitian bahwa permen terong pipit yang terbaik adalah 
pada perlakuan D (1000 gr gula pasir/bb) dengan kadar gula total $43.824 \%$ dan kadar air $5.5482 \%$. Dari hasil uji kadar gula sakarosa sudah memenuhi standar SNI yaitu kadar sakarosa min $40 \% / b b$, namun pada uji kadar air belum memenuhi standar SNI yaitu kadar air maksimal 3,5\%/bb.

\section{Saran}

Pada pembuatan permen terong pipit memiliki rasa dan warna yang kurang menarik. Oleh karena itu, sebaiknya pada penelitian selanjutnya dalam pembuatan permen terong pipit perlu ditambahkan lagi bahan tambahan pangan berupa rasa dan pewarna alami sehingga dapat menciptakan rasa dan warna yang menarik.

\section{DAFTAR PUSTAKA}

Aji, Agus, 2012. Manfaat Buah Cepokak. http://agusajiherba.blogspot.com. Diakses pada tanggal 05 Desember 2014.

Amin, Asni. 2009. Obat Asli Indonesia. Makassar : Universitas Muslim Indonesia Press.

Athy,S.H.,1979. Studi Pembuatan Nata de Nanas. Laporan Praktik Lapang. Jurusan Teknologi Pertanin Universitas hasanuddin, Makassar.

Buckle, K.A., R.A. Edwards., G.H Fleet and M. Wootton., 1987. Food Science dalam Ilmu Pangan. Penerjemah Hari Purnomo dan Adiono. Universitas Indonesia, Jakarta.

Faridah, Anni, dkk. 2008. Patiseri Jilid 3. Departemen Pendidikan Nasional : Jakarta

Heyne, K, 1987. Tumbuhan Berguna Indonesia Jilid ke-3. Jakarta : Yayasan Sarana Warna Jaya.

Hidayat, Rachmat, 2014. Resume Terong. http://rachmathidayat1197.

blogspot.com. Diakses pada tanggal 05 Desember 2014.

Hasniarti. 2012. Studi Pembuatan Permen Buah Dengen. Skripsi. Program Studi Ilmu Dan Teknologi Pangan Jurusan Teknologi Pertanian Fakultas Pertanian Universitas Hasanuddin : Makassar.

Jackson, E.B. 1995. Sugar Confectionery Manufacture. Blackie Academic and Profesional. London.

Luthony, TL. 1990. Tanaman Sumber Pemanis. Penebar Swadaya. Jakarta

Mahfud, 2013. Khasiat lain dari terong pipit. http://beritabolauptodate. blogspot.com. Diakses pada tanggal 5 April 2015.

M. Sholeh. 1978. Penataran Pengusaha Kecil Kembang Gula di Daerah Semarang dan Sekitarnya. Semarang : Balai Penelitian Semarang.

Mc. William. 2001. Food Experimental Prespectives. 4th edition. Prentice Hall, Inc. New Jersey.

Nuzulqi, Evi Ramdhani. 2015. Mempelajari Perbandingan Sukrosa dengan Glukosa dan Lama Pengeringan terhadap Karakteristik Fruit Leather Stroberi (Fragaria chiloensis L. var. earlibrite). Teknologi Pangan. Universitas Pasundan.

Pratiwi, dkk., 2008. Pembuatan Permen (Soft Candy). http://nurvikahadistiani.blogspot.com. Diakses pada tanggal 5 Desember 2015.

Rana, Dian, 2011. Bahan Baku UtamaPermen.http://dianscatzy.b logspot.com. Diaksespadatanggal 05 Desember 2014.

Rubianty dan Berty Kaseger. 1985. Kimia Pangan. Badan Kerja Sama Perguruan Tinggi Negeri 
Indonesia Bagian Timur. Ujung Pandang.

Rampengan, V.J dkk .1985. Dasar-dasar Pengawasan Mutu Pangan.

Badan Kerja sama Perguruan Tinggi Negeri Indonesia Bagian Timur, Ujung Pandang.

Soekarto, S. T. 1985. Penilaian Organoleptik untuk Industri Pangan dan Hasil Pertanian. Bhratara Karya Aksara, Jakarta.

Sirossiris, 2010. Pembuatan Permen Hard Candy. https://lordbroken. wordpress.com. Diakses tanggal 19 juni 2015.

Standar Nasional Indonesia. 0131440. 2005. Gula Kristal Putih. Jakarta: Badan Standarisasi.

Susanti, A, 2014. Asam Jawa Makalah. http://susantiaria.blogspot.com. Diakses pada tanggal 05 April 2015.
Sudarmaji. S. Bambang dan Suhardi. 1997. Prosedur Analitik untuk Bahan Maknan dan Pertanian Liberty. Yogyakarta, 189 hal.

Triasmara, Wahyu, 2014. Manfaat Buah Rimbang atau Cepokak bagi Kesehatan.

http://kesehatan.kompasiana.com /alternatif/2014/08/03/back-tonature-manfaat-takokak-rimbangbagi-kesehatan-671226. Diakses pada tanggal 01 April 2015.

Widowati, E., 2006. Pengaruh Lama Perendaman dengan Larutan Kapur Tohor $\mathrm{Ca}(\mathrm{OH}) 2$ Pada Kulit Buah Manggis Terhadap Kualitas Kembang Gula. Skripsi Fakultas Teknik Universitas Negeri Semarang, Semarang.

Winarno, F.G. 2008. Kimia Pangan dan Gizi. Gramedia Pustaka Utama : Jakarta. 